\title{
Article
}

\section{Developing a case based learning curriculum with a salutogenic perspective}

Ridley, Neesha and Byrom, Anna

Available at http://clok.uclan.ac.uk/23812/

Ridley, Neesha and Byrom, Anna (2018) Developing a case based learning curriculum with a salutogenic perspective. Midwifery, 64 . pp. 124-127. ISSN 0266-6138

It is advisable to refer to the publisher's version if you intend to cite from the work. http://dx.doi.org/10.1016/j.midw.2018.06.006

For more information about UCLan's research in this area go to http://www.uclan.ac.uk/researchgroups/ and search for < name of research Group>.

For information about Research generally at UCLan please go to http://www.uclan.ac.uk/research/

All outputs in CLoK are protected by Intellectual Property Rights law, including Copyright law. Copyright, IPR and Moral Rights for the works on this site are retained by the individual authors and/or other copyright owners. Terms and conditions for use of this material are defined in the policies page.

\section{CLoK}

Central Lancashire online Knowledge www.clok.uclan.ac.uk

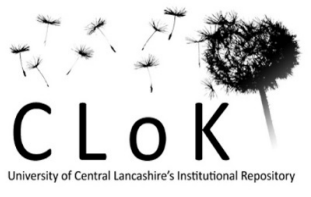




\section{Developing a case based learning curriculum with a salutogenic perspective.}

Neesha Ridley BSc (Hons), PGCertHE. RM, FHEA. Senior lecturer and course leader at the University of Central Lancashire.

Anna Byrom BSc (Hons), PGCertHE. Rm, FHEA. Senior lecturer and course leader at the University of Central Lancashire.

\section{Abstract}

At the University of Central Lancashire, in the North West of England, United Kingdom (UK) the midwifery team introduced a new and innovative case-based learning (CBL) curriculum for the undergraduate midwifery course. $\mathrm{CBL}$ is a student-centred approach to teaching and learning and encourages students to learn from each other, develop essential skills when caring for women and families including collaborative working and effective communication. In this article we share our approach and experiences of developing and delivering a CBL curriculum informed by salutogenesis, including how it enabled us to support effective learning and skill development for women and families.

\section{Setting the scene for a new curriculum}

In 2012, as part of our revalidation process we set about planning our new pre-registration midwifery curriculum. Developing and designing curriculums for learning in midwifery education can be arduous and complex. There is an imperative to balance regulatory, professional and educational requirements alongside the variable, shifting needs of childbearing women and families. To ensure our curriculum was 'fit for purpose' we canvased relevant literature at the time (NMC 2011, DoH 2010, Francis, 2013) and engaged a relevant stakeholder group of clinicians, academics, students, serviceusers and wider multi-disciplinary team members. We began by locating a shared vision of the 'ideal' midwife as outlined in Figure 1. 
Figure 1 - characteristics of an 'ideal' midwife generated from stakeholder meetings (adapted from Byrom, Perez-Botella and Heneghan 2016).

$\begin{array}{ll}\text { Vision - 'with-woman' } & \\ \text { central to the } & \text { - Compassionate } \\ \text { programme } & \text { - Patient } \\ & \text { - Calm } \\ & \text { - Skilled } \\ \text { Salutogenic practitioner: } & \text { - Eensitive } \\ \text { Informed by Antonovsky's } & \text { - Embraces change } \\ \text { SOC construct including } & \text { - Resilience } \\ \text { comprehensibility, } & \text { - Communicator } \\ \text { manageability and } & \text { - Collaborator } \\ \text { meaningfulness } & \text { - Educator } \\ & \text { - Promotes positive experiences } \\ & \text { - Reflective practitioner } \\ & \text { - Emotional intelligence }\end{array}$

This vision informed the development of a shared philosophy that steered the selection of an appropriate curriculum model. Our vision and philosophy helped in articulating relevant aims and objectives for the curriculum: to nurture the development of compassionate, competent, informed and caring midwives of the future.

\section{The salutary curriculum philosophy}

We turned to Antonovsky's (1979) philosophy of salutogenesis which offers a philosophical orientation that moves beyond the purely pathological paradigms of dichotomising normal, abnormal, low-risk and high-risk childbearing. Salutogenesis perceives health on a transient continuum situated within the context of our environment and social lives (Lindstom \& Ericksson 2010). As a philosophy, salutogenesis is well aligned with midwifery, which embraces being 'with-woman' and understanding childbearing as a healthy physical and psycho-social phenomenon.

We aimed to select a curriculum that would embrace Antonovsky's Sense of Coherence (SOC) construct, a global orientation in which an individual perceives life as comprehensible, manageable and meaningful (Mittelmark \& Bauer, 2017). SOC theory applied to both how we supported student well-being and in turn encouraged them to enhance health and well-being of the women and families 
in their care. Informed by the concepts of woman-centred and family-centred care, underpinned by salutogenesis, the midwifery team selected a CBL curriculum model to design a suitable midwifery pre-registration degree programme.

\section{Case-based learning as a curriculum design - creating a sense of coherence}

Case-based learning (CBL) is an approach to curriculum design and delivery. It is defined in numerous ways across disciplines (Thistlethwaite et al 2012) and closely aligned to Problem Based Learning (PBL). CBL differs to PBL by providing more structure to enhance student development and achievement of specified learning outcomes. Crucially, CBL encourages 'guided inquiry' supported with a range of resources (literature, videos and core learning activities) pulled together through active tutor facilitation and feedback (Srinivasan, Wilkes, Stevenson, Nguyen and Slavin 2007). CBL embraces and builds upon other approaches (e.g. PBL and definition-based learning), offering an educational paradigm with core characteristics including:

$>$ Development of 'real-life' cases to review and critique

$>$ Small group learning (4-8 students)

$>$ Lecturers as facilitators of learning

$>$ Active participation from students

$>$ Peer learning and sharing

\section{Why CBL? Rationale for selection}

With CBL, students develop skills in analytical thinking and reflective judgment by reading and discussing complex, real-life scenarios. This enables learners to put theory into practice in the safety of the classroom setting, which is ideal for midwifery, where students spend equal time in clinical and education-based settings (Wood, 2003; Thistlethwaite et al, 2012). Additionally, exploration of specific, practice-informed case studies aligns with salutogenesis theory. Students are supported to consider the physical, psycho-social, cultural and professional factors that influence midwifery and how they can enhance childbearing women and families' sense of coherence through improved manageability, comprehensibility and meaningfulness (Byrom et al 2015). CBL enables students' exploration of specified learning outcomes, using critical thinking rather than relying on the lecturers dispensing of wisdom (Taylor, 2014). As a student centred approach to teaching and learning, CBL also supports peer-learning developing collaborative working and communication skills as outlined in Table 1. 


\begin{tabular}{|c|c|c|}
\hline Benefit & How & Impact \\
\hline $\begin{array}{l}\text { Preparation for placement and } \\
\text { practice }\end{array}$ & $\begin{array}{l}\text { Engaging with 'real-life' cases } \\
\text { and scenarios in the safety of } \\
\text { the classroom environment. }\end{array}$ & $\begin{array}{l}\text { Building confidence to care for } \\
\text { women and families. } \\
\text { Development of clinical and } \\
\text { caring skills. Closes the theory- } \\
\text { practice gap. }\end{array}$ \\
\hline $\begin{array}{l}\text { Collaborative and } \\
\text { communication skills }\end{array}$ & $\begin{array}{l}\text { Students working in small } \\
\text { teams and sharing their ideas } \\
\text { through regular feedback } \\
\text { sessions. }\end{array}$ & $\begin{array}{l}\text { Enables students to become } \\
\text { effective members of a multi- } \\
\text { disciplinary team. }\end{array}$ \\
\hline $\begin{array}{l}\text { Encourages active and } \\
\text { motivated learners }\end{array}$ & $\begin{array}{l}\text { Blend of directed and self- } \\
\text { directed study. }\end{array}$ & $\begin{array}{l}\text { Helps to develop autonomous } \\
\text { practitioners with life-long } \\
\text { learning skills. }\end{array}$ \\
\hline $\begin{array}{l}\text { Improves research and critical } \\
\text { evaluation skills }\end{array}$ & $\begin{array}{l}\text { Through research clubs and } \\
\text { searching for and sharing } \\
\text { current literature and } \\
\text { evidence to support weekly } \\
\text { feedback sessions. }\end{array}$ & $\begin{array}{l}\text { Enhanced evidence-based } \\
\text { practice. Improved confidence } \\
\text { to access and critique research } \\
\text { and literature. }\end{array}$ \\
\hline Develops reflective practice & $\begin{array}{l}\text { Weekly reflection sessions } \\
\text { exploring learning and } \\
\text { personal development. }\end{array}$ & $\begin{array}{l}\text { Develops self-awareness and } \\
\text { ensures ongoing practice } \\
\text { development. }\end{array}$ \\
\hline \multicolumn{3}{|l|}{ Adapted from Williams (2005) } \\
\hline
\end{tabular}

Identification of these established benefits reassured us that CBL would enable us to meet our course aims, objectives, and vision for the future midwife. We have charted benefits through ongoing formative and summative evaluation (questionnaires, feedback events and interviews) with the midwifery lecturing team and all students during each stage of implementation. Implementing CBL has been a learning journey for us as a team. 


\section{Making it work in practice - our step-by-step guide}

It was essential that our curriculum reflected the standards expected by the UK Nursing and Midwifery Council (NMC) and vision outlined in stakeholder meetings (NMC, 2009). To respond to these requirements, we developed core curriculum themes (Figure2). The three core themes: 'the midwife', 'the woman and her childbearing experience' and 'the baby and the family', became the focus of the three core modules that students engage with during their training. The learning outcomes for each module are addressed collectively through structured CBL 'cases' to allow development of midwifery practice.

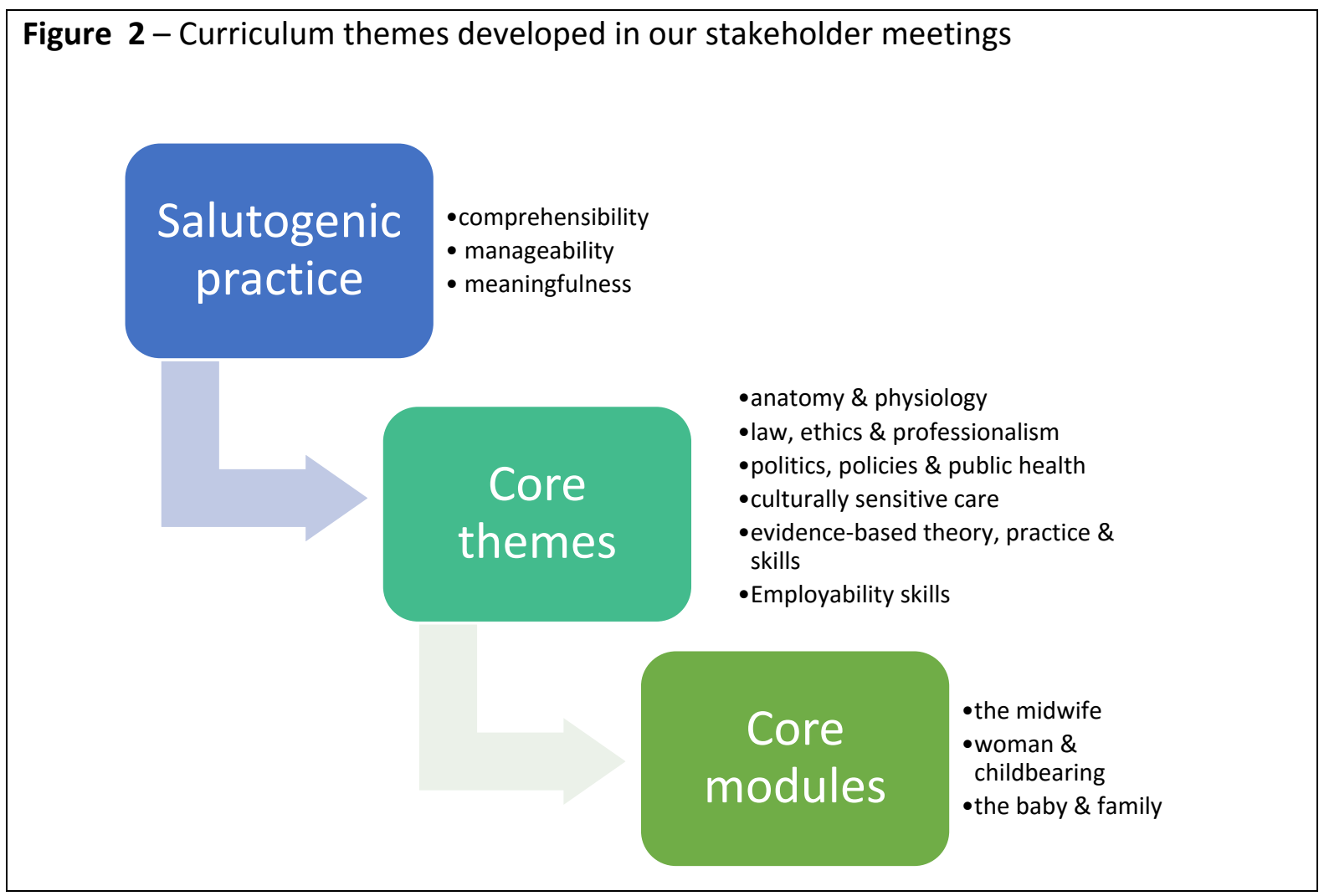

\section{$\underline{\text { CBL practicalities }}$}

Team work was crucial as we developed the CBL curriculum content and delivery structure. Figure 3 identifies the team roles and responsibilities for CBL. The development phase was resource intensive, as we required whole-team input to write and facilitate individual sessions, however experience has 
enabled us to adapt curriculum design and delivery to improve our efficiency. We learnt to balance work-load across the team and reduced the need for multiple facilitators by organising for case-leads to take feedback from all groups. We also recognised the importance of having a year lead to oversee module development and ensure students receive adequate support throughout the academic year. Year leads work carefully with module leaders, ensuring learning outcomes are met, and students' sense of coherence maintained throughout the year.

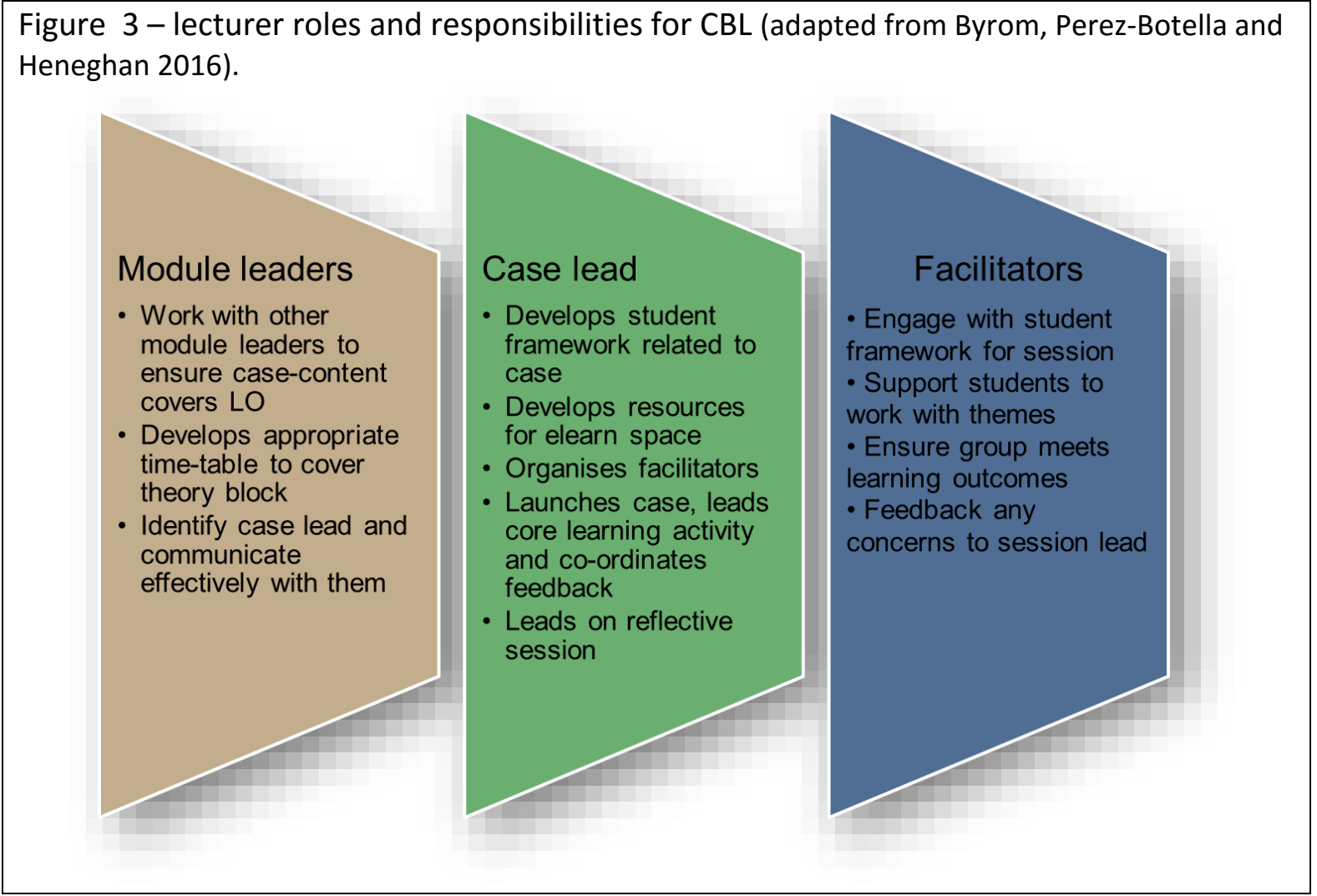

Students are organised in small groups to engage with our CBL curriculum. Group membership is rotated at each theory block to support student relationship growth across the cohort. Small group work increases student engagement and improves confidence during group feedback. Importantly small group work strengthens students' team work, reflection and communication skills - essential for midwifery practice and compassionate care.

Student engagement with the curriculum follows a clear process (Figure 4) to promote consistency and quality across cases and between case leads/facilitators. This is an essential feature of curriculum development. Having a simple and structured framework for each case, enables students to assimilate with a new approach to learning. Regular communication, evaluation and feedback between facilitators, students and course leaders ensures the course 
content and cases are adapted, reviewed and revised to respond to individual, group and class needs. The responsive capacity of CBL has been an overwhelming benefit. It has enabled us to care for students' needs and to respond to our own needs as midwifery educators.

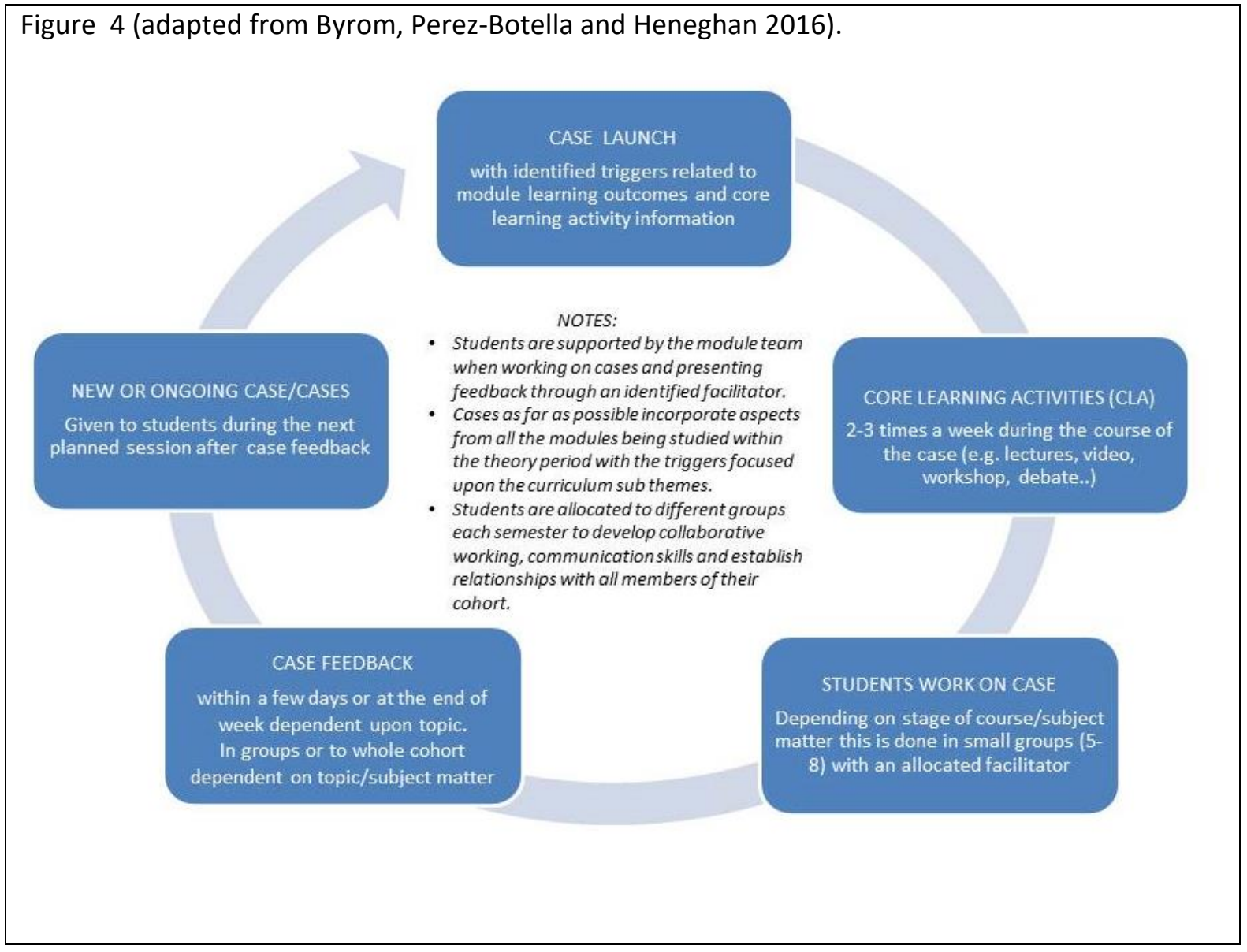

\section{Blended learning considerations}

Within $\mathrm{CBL}$, learners are encouraged to use online resources to research the content of the case and develop their knowledge. Online resources represent an excellent opportunity for the learner to undertake self-directed study in their own time and at their own pace (RCM, 2011). The guidance provided by lecturers allows learners to feel supported, encouraging students and educators to develop a reciprocal relationship, essential for learning. Regular communication, evaluation and feedback between educators, students and course leaders ensures the course content and cases are adapted, reviewed and revised to respond to individual, group and class needs.

\section{$\underline{\text { Our learning and reflections }}$}


The adaptation of a CBL approach has been an exciting adventure for the education team and students alike. As educators there was a concern that leaving students to learn for themselves may affect achievement of the learning outcomes. This was accompanied by apprehension that our role as teacher was in some way diminished - that we were offering a reduced service with CBL due to less formal teaching. However, CBL ensures consistent engagement, learning and development for individual students. Our new role as facilitators encouraged a new approach of support and leadership, working together with students and learning in collaboration with them.

By providing the opportunity for students to question, collaborate, generate ideas of how to produce and deliver information to their peers, we can see that they have developed skills to problem solve, with minimal guidance. Through peer review and critical reflection, students can utilise higher level thinking skills and with the peer support network, they can understand, retain and apply their learning to clinical situations. We believe $\mathrm{CBL}$ is best developed through the SOC dimensions of comprehensibility, manageability and meaningfulness.

\section{Conclusion}

In the UK we face exciting opportunities as the NMC work to revise the standards of proficiency for midwifery education. These standards will influence the future of midwifery education and practice. We feel that our CBL curriculum offers an ideal curriculum design to respond to the Lancet series Quality Framework for Maternal and Newborn Health (Renfrew et al 2014) that looks to be providing an excellent platform for informing the review of the standards.

\section{$\underline{\text { References }}$}

Antonovsky A (1979) Health, Stress and Coping. San Francisco, Jossey-Bass

Byrom A, Heneghan S and Perez-Botella M (2015) With-woman, with-student: developing a woman and family-centred recruitment strategy and curriculum for caring in Downe $S$ and Byrom S (eds) The Roar Behind the Silence, Pinter and Martin, London.

Department of Health (2010) Midwifery 2020: Delivering expectations, London, UK HMSO 
Francis, R. (2013) Report of the Mid Staffordshire NHS Foundation Trust Public Inquiry. [online] Accessed at https://www.gov.uk/government/publications/report-of-the-mid-staffordshire-nhsfoundation-trust-public-inquiry

Lindstrom, B., \& Eriksson, M. (2006) Contextualizing salutogenesis and Antonovsky in public health development. Health Promotion International. 21 (3) pp. 238-244

Mittelmark, M. B and Bauer, G. F (2016). The Handbook of Salutogenesis. Springer, London.

Nursing and Midwifery Council [NMC] (2009) Standards for pre-registration Midwifery Education [online] Accessed at https://www.nmc.org.uk/globalassets/sitedocuments/standards/nmcstandards-for- preregistration-midwifery-education.pdf

Nursing and Midwifery Council [NMC] (2011) The MINT Project, London NMC.

Renfrew M, McFadden A, Bastos M, Campbell J, Channon A et al (2014) Midwifery and quality care: findings from a new evidence-informed framework for maternal and newborn care, The Lancet, Vol. 384, No 20, pp1129-1141

Royal College of Midwives [RCM] (2011) Delivering the pre-registration midwifery curriculum [online] https://www.rcm.org.uk/learning-and-career/learning-and-research/ebmarticles/delivering-the-pre-registration-midwifery

Srinivasan M, Wilkes M, Stevenson F, Nguyen T and Slavin S (2007) Comparing problem-based learning with case-based learning: effects of a major curricular shift at two institutions, Academic Medicine, Vol. 82, Issue 1, p74-82.

Taylor, B.S (2014) What are the similarities between case based learning and problem based learning? [online] https://www.researchgate.net/post/What are the SIMILARITIES and DIFFERENCES between CBL Case-Based Learning and PBL Problem-Based Learning

Thistlethwaite, J. E., Davies D, Ekeocha S, Kidd J M, MacDougall C, Matthews P, Purkis J, Clay D. (2012) The effectiveness of case-based learning in health professional education. A BEME systematic 
review: BEME Guide No. 23. Med Teach. 2012;34 (6). [Online]

http://www.ncbi.nlm.nih.gov/pubmed/22578051

Wood, D (2003) Problem based learning. British medical journal. Vol 326 No 328. [online] http://www.bmj.com/content/326/7384/328

Williams, B (2005) Case based learning - a review of the literature: is there scope for this educational paradigm in prehospital education? [online] Accessed at

http://emi.bmi.com/content/22/8/577 